\title{
Supporting sustainability by promoting online purchase through enhancement of online convenience
}

\author{
Swapan Kumar Saha ${ }^{1} \cdot$ Paulo Duarte ${ }^{2}$ D . Susana C. Silva ${ }^{3} \cdot$ Guijun Zhuang $^{1}$
}

Received: 19 July 2019 / Accepted: 30 July 2020 / Published online: 5 August 2020

(c) Springer Nature B.V. 2020

\begin{abstract}
Online purchases can support environmental sustainability by reducing the number of shopping trips. The purpose of this article is to understand how online convenience may be used to increase online purchase intention and therefore contribute to environmental sustainability. Employing a snowball sampling technique data from 226 Chinese respondents were used with Least Squares Structural Equation Modelling (PLS-SEM) to test the research hypotheses. Findings suggest that customers with experience have a strong effect on the relationship between service convenience and customer satisfaction. It is also found that satisfied customers desired to stay longer and are willing to pay more. From a theoretical point of view, this study fills several gapes by extending previous work that investigates the impact of online convenience on customer satisfaction and behavioral intention by revealing the novelty impact on the willingness to pay and desire to stay. From a managerial standpoint, the findings help managers considering doing businesses or planning to do businesses in China and for companies committed to reducing their carbon footprint in understanding how they can use online convenience to stimulate online purchases among their clients and consequently becoming more environmentally friendly and socially responsible.
\end{abstract}

Keywords Service convenience $\cdot$ Online shopping experience $\cdot$ Online customer satisfaction · Behavioral intention · Willingness to pay more $\cdot$ Environmental sustainability

Paulo Duarte

pduarte@ubi.pt

Swapan Kumar Saha

swapan@iubat.edu

Susana C. Silva

ssilva@porto.ucp.pt

Guijun Zhuang

zhgj@mail.xjtu.edu.cn

1 Department of Marketing, Xi'an Jiaotong University, Xi'an 710049, China

2 NECE - Research Centre in Business Sciences, Universidade da Beira Interior, Rua Marquês d’Ávila e Bolama, 6201-001 Covilhã, Portugal

3 Católica Porto Business School, Universidade Católica Portuguesa, Rua Diogo Botelho, 1327, 4169-005 Porto, Portugal 


\section{Introduction}

The capability to ease consumers' time, energy, and effort when purchasing has been coined as service convenience (Farquhar and Rowley 2009; Seiders et al. 2007). Online convenience, on its hand, can be considered a form of service convenience and it has been one of the main supporters of an individual's readiness to adopt online purchasing (Jiang et al. 2013). Online purchase can be regarded as a more environmentally sustainable option as it reduces trips to multiple physical stores (Bertram and Chi 2018; Edwards et al. 2009, 2010; Van Loon et al. 2014), supporting a more sustainable supply chain management (Rajesh 2020b). Globally, governments are revising their policies to assure more environmental behavior from companies and consumers (Sharma et al. 2019). In this fight, companies could become an important ally by promoting online purchase. However, there are still many customers that are not buying online because they are inexperienced in the use of the channel (Liebermann and Stashevsky 2002; Soopramanien 2011). Experience is therefore crucial to forming customers' perceptions, regarding their expectations about online retailers (Pappas et al. 2014; Xiao et al. 2019) since rewarding experiences with online shopping significantly produces positive attitudes in both the pre- and post-purchase stages (Frambach et al. 2007; Giannakos et al. 2011), and these may contribute for the overall firm's sustainability performance (Rajesh 2020a). Prior studies provide practical evidence for the positive impact of experience on both customer satisfaction and willingness to repurchase (Tsao et al. 2016). In fact, consumers with low online experience feel more fear about online shopping (Holloway et al. 2005) and are worse judging the advantages and dangers of products (Soopramanien 2011) as experienced online shoppers display higher levels of perceived access convenience when compared to less experienced online shoppers who tend to get more anxious (Bernard and Makienko 2011; Wan et al. 2012).

Service convenience (SVC) is highly relevant for online retailers as it influences shoppers' preferences and perceptions about the service and promotes buyers' satisfaction (Ostrom et al. 2015). Prior studies on online shopping have treated the service convenience as a predictor variable, jointly with customer service, loyalty, and trust, all affecting outcome variables such as customer satisfaction, behavioral intention, repurchase intention and e-word of mouth (Colwell et al. 2008; Duarte et al. 2018; Jiang et al. 2013; Kaura et al. 2015; Seiders et al. 2007). The investigation has long approved the positive effect of service convenience components, namely upon service experience and consumer satisfaction (Benoit et al. 2017; Leonard 2016). However, few studies have focused on the online environment to investigate the relationship between online service convenience, online customer satisfaction, behavioral intention, willingness to pay more (WPM), and desire to stay (DTS) on the online store. Given this limited nature in the scope of existing research, the main objective of this study is to extend prior research by investigating the influence of SVC on customer satisfaction to purchase products and services in the online market. Additionally, the study examines the role of the online shopping experience as a moderator of the relationship between service convenience and online customer satisfaction, and the link between the later and behavioral intention, wiliness to pay more, and desire to stay.

\section{Theoretical background}

Service convenience is a major element influencing shoppers' adoption of online shopping (Roy et al. 2017); therefore it is not surprising that online retailers made significant investments reinforcing online convenience aspects of their service offerings, which will 
additionally grant them improvements in their reputation among stakeholders and shareholders by diminishing their digital footprint (Rajesh 2020a). From the consumer point of view, Mathiyazhagan et al. (2019) indicate that convenience is among the biggest challenges for green products. As a result, SCV became of significant interest to both retailers and researchers. Recent research found that there is still no consensus on the component of online convenience (Duarte et al. 2018). Based on an online perspective (Beauchamp and Bednarz 2010) develop a general concept of convenience, which is similar to online convenience. More recently Jiang et al. (2013) developed five categories model for SCV: access, search, evaluation, transaction, and possession/post-purchase convenience, based on the customer decision-making process. These categories were later used by Duarte et al. (2018) to study the role of online convenience in online consumer behavior among Portuguese young consumers. SCV dimensions, as suggested by Berry et al. (2002), were extensively applied, namely by Colwell et al. (2008) in Canadian cellular and web services, in the Indian grocery retail by Aagja et al. (2011), and in the Indian banking sector and mobile services by Kaura (2013) and Roy et al. (2018).

\subsection{Online service convenience concept and dimensions}

Convenience represents an indicator of the time and effort consumers must apply when buying products. Today, consumers feel that they have less time available and therefore favor sellers offering the best convenience-based offer in terms of search, access, acquisition, and use (Bhatnagar et al. 2000). A significant part of the investigation on e-commerce has treated convenience as one more of the predictor variables (Colwell et al. 2008); however, shopping convenience is a major motive for consumers to access online retailers' websites (Jayawardhena et al. 2007), Researchers pointed out that online service convenience provides customers with time-saving and minimization efforts (Jiang et al. 2013), then consumers with larger time constraints are more likely to focus on convenience when purchasing or consuming a service (Berry et al. 2002).

It is accepted that convenience comprises numerous facets and that service convenience is multidimensional (Brown 1990; Duarte et al. 2018). Based on Jiang et al. (2013) five dimensions model for SVC, in the following sections, each dimension is discussed and the study hypotheses are proposed.

\subsubsection{Access convenience}

Access convenience (ACC) refers to increased control provided to buyers to save time and energy in reaching the service (Farquhar and Rowley 2009). Prior research has mentioned that experienced online shoppers display superior perceived access convenience when compared to inexperienced online customers (Bernard and Makienko 2011; Chen et al. 2009). Access convenience is a prerequisite for all other types of consumer shopping convenience because if a customer is not able to access the provider, then he/she will never have the chance to use the service (Duarte et al. 2018; Seiders et al. 2000). However, access convenience is only part of shopper's evaluation of a retailer's online shopping convenience. Based on this, we propose that there is a positive relationship between the customer's perception of access convenience and customer satisfaction (H1a). 


\subsubsection{Search convenience}

Search convenience portrays the shopper's assessment of the time and energy needed to find and decide on the products they wish to buy (Beauchamp and Ponder 2010; Dabholkar 1996). Search convenience can, therefore, be conceptualized as the degree of user-friendliness of a retailer web site to enable shoppers to easily find what they are looking for (Benoit et al. 2017). Online shoppers can search for products and contrast prices without physically visiting numerous locations (Jiang et al. 2013). Past literature acknowledged that the more efficient is the retailers attempt in facilitating customers' product searches, the quicker and easier it becomes the customer's journey (Kollmann et al. 2012). Accordingly, search convenience assists shoppers throughout the shopping process by helping them shape the buying decision (Beauchamp and Ponder 2010). Thus, the increase of search convenience efficiency has a positive effect on customer satisfaction and customer behavioral attitude (Beauchamp and Ponder 2010; Roy et al. 2018; Seiders et al. 2000). Therefore, it is proposed that there is a positive relationship between the customer's perception of search convenience and customer satisfaction (H1b).

\subsubsection{Evaluation convenience}

Evaluation convenience represents how easy consumer can understand product descriptions by using various presentation aspects on the retailer's website (Jiang et al. 2013). Using the available elements and tools, the consumer must be able to get detailed information about the product and check other consumers' comments and reviews on their own experience with the product before ordering (Jiang et al. 2013). A recent study provides evidence that evaluation convenience has a significant effect on customer satisfaction (Duarte et al. 2018). Accordingly, it is proposed that there is a positive relationship between the customer's perceptions of evaluation convenience and customer satisfaction (H1c).

\subsubsection{Transaction convenience}

Colwell et al. (2008) indicate that transaction convenience involves the perception of time and energy needed to conclude the service purchase. Previous studies have shown that flexible transactions process increases online customer efficiency and the customer can complete shopping without waiting in the queue (Wolfinbarger and Gilly 2012). Online buyers are in virtual checkouts where they can finish the business deal by themselves when ready (Gupta et al. 2017). Yet, special attention should be devoted to payment, since complex payment methods repeatedly inhibit online buyers from concluding the purchase at the last moment (de Kerviler et al. 2016; Javadi et al. 2012), generating negative effects on customer satisfaction (Chang and Polonsky 2012). Consequently, we propose that there is a positive relationship between the customer's perceptions of transaction convenience and customer satisfaction (H1d).

\subsubsection{Possession and post-possession convenience}

Possession convenience is about ensuring that customers obtain desired products within reasonable time and effort (Seiders et al. 2000). In an online setting, customers must wait for the orders to be handled, dispatched, and delivered before taken ownership of the product (Beauchamp and Ponder 2010; Duarte et al. 2018). Furthermore, failure of on-time 
delivery, risks of incomplete orders, damaged goods have also negative effects on the online experience (Houston et al. 1998; Jiang et al. 2013). The following stage, the postpossession involves the experience of the consumer when he/she needs to contact the retailers after the sale is complete to initiate a customer service claim (Berry et al. 2002; Gwinner et al. 1998; Seiders et al. 2007; Zeithaml et al. 2013). Hence, it is proposed that there is a positive relationship between both the customer's perceptions of possession (H1e) and post-possession (H1f) and customer satisfaction.

\subsubsection{Decision convenience}

Decision convenience is a key part of the decision-making process when consumers have to decide among the multiple sources from whom they should purchase a specific service (Yang 2012). Lloyd et al. (2014) argue that decision convenience is even significant before the service exchange and Zeithaml et al. (1996) stress the importance of common fate, in consumer's perceived degree of avoidance of time and effort to make the decision or whether to use a service or not. The positive link between decision convenience and customer satisfaction has been suggested, however, the positive impact was reported by Thuy (2011), and a negative effect was described by Chang and Polonsky (2012). Thus, we propose that there is a positive relationship between the customer's perceptions of decision convenience and customer satisfaction ( $\mathrm{H} 1 \mathrm{~g})$.

\subsection{Outcomes of convenience}

Overall customer satisfaction is the result of a post-consumption evaluation involving both cognitive and affective components (Ameer 2013; Jun et al. 2004; Mano and Oliver 1993). Several researchers showed that post-consumption satisfaction is positively influenced by online store convenience and, therefore, by SVC (Hsu et al. 2010; Koo et al. 2008; Thuy 2011). When customers enjoy the benefit of a convenient and easy service satisfaction increases and they tend to use them again (Hsu et al. 2010). Indeed, service convenience has a positive effect on online customer satisfaction through behavioral intentions (Duarte et al. 2018; Jiang et al. 2013; Lloyd et al. 2014; Roy et al. 2018). Therefore, it is proposed that there is a positive association between customer's satisfaction and behavioral intentions (H2).

Prior studies find that overall service convenience also improves behavioral intentions through satisfaction (Colwell et al. 2008; Duarte et al. 2018; Roy et al. 2018; Seiders et al. 2007). Lee and Lin (2005) suggest that satisfaction has a positive effect on the intention to repurchase.

Willingness to pay refers to the maximum amount of money a customer is willing to spend on product or service (Cameron and James 1987; Jedidi and Zhang 2002; Krishna 1991). In recent studies by Pham and Ahammad (2017) advocated that customer satisfaction is an important predictor for willingness to pay more. However, other researchers found that some customers are not interested in willing to pay more even though they are satisfied in their previous purchases (Homburg et al. 2005; Kushwaha and Kaushal 2016; Pham and Ahammad 2017). Accordingly, we propose that there is a positive relationship between customer satisfaction and willingness to pay (H3).

At the same time, online retailers need to understand consumers' desire to stay longer because satisfied customers stay longer and the more they stay the more they are expected to spend (Kim et al. 2007). Previous studies have provided empirical support for the 
significant relationship between satisfaction and desire to stay. According to Bitner (1992), customers respond to a service based on their level of satisfaction through the service offer, and their desire to stay with that service increases when they are satisfied (Lam et al. 2011). The literature also acknowledges that greater satisfaction and the quality of service increase the time of stay and intention to revisit (Fiore et al. 2000; Wakefield and Blodgett 1996; Yalch and Spangenberg 1990). Thus, it is proposed the existence of a positive association between customer satisfaction and the desire to stay (H4).

\section{The moderating role of online shopping experience}

The online shopping experience is the process of acquiring knowledge and experience used for analyzing, searching, and comparing products and services online (Wan et al. 2012). Researchers argue that online purchases are risky than offline purchase (Goyal et al. 2013; Laroche et al. 2005) but customers with increased online experience are better evaluators of the advantages and threats, namely the ones related to personal information leakage and unauthorized use their credit cards (de Kerviler et al. 2016; Falk et al. 2007; Soopramanien 2011) which lead them to feel less hesitant to shop online (Bernard and Makienko 2011; Javadi et al. 2012). Experienced online customer goes online more often because of selfconfidence they have built (Tsao et al. 2016; Yeo et al. 2017). Additionally, a customer with a superior online shopping experience is expected to convey a greater desire to stay. Yeo et al. (2017) anticipate that experience in online shopping significantly affect customer convenience motivation. However, if a consumer is not able to conveniently approach the retailer, then he/she has not the chance to use the service and evaluate it. Based on this we propose that the positive influence of: (a) access; (b) search; (c) evaluation; (d)transaction (e) possession; (f) post possession; (g) decision convenience on customer satisfaction is moderated by online experience (H5).

Table 1 summarizes the hypotheses for the current investigation.

A graphical representation of the conceptual model is presented in Fig. 1.

\section{Methodology}

\subsection{Data collection instrument}

The data for the current research were assembled using an online questionnaire comprising 52 questions. The questionnaire was developed and made available in December 2018 and was online for 10 weeks. As target respondents were Chinese and the original scales were in English, the questionnaire was translated to Chinese by an expert. The purpose of translating the questionnaires to Chinese was to avoid misunderstanding and increase the response rate.

\subsection{Measures}

Two new items were developed for analyzing desire to stay ("I am getting more product information to stay long at this online store" and "I can find a more verity option for spending a long time at this online store"). Equally for willingness to pay two items were also developed ("I do not bother to pay more to make sure the company provides 


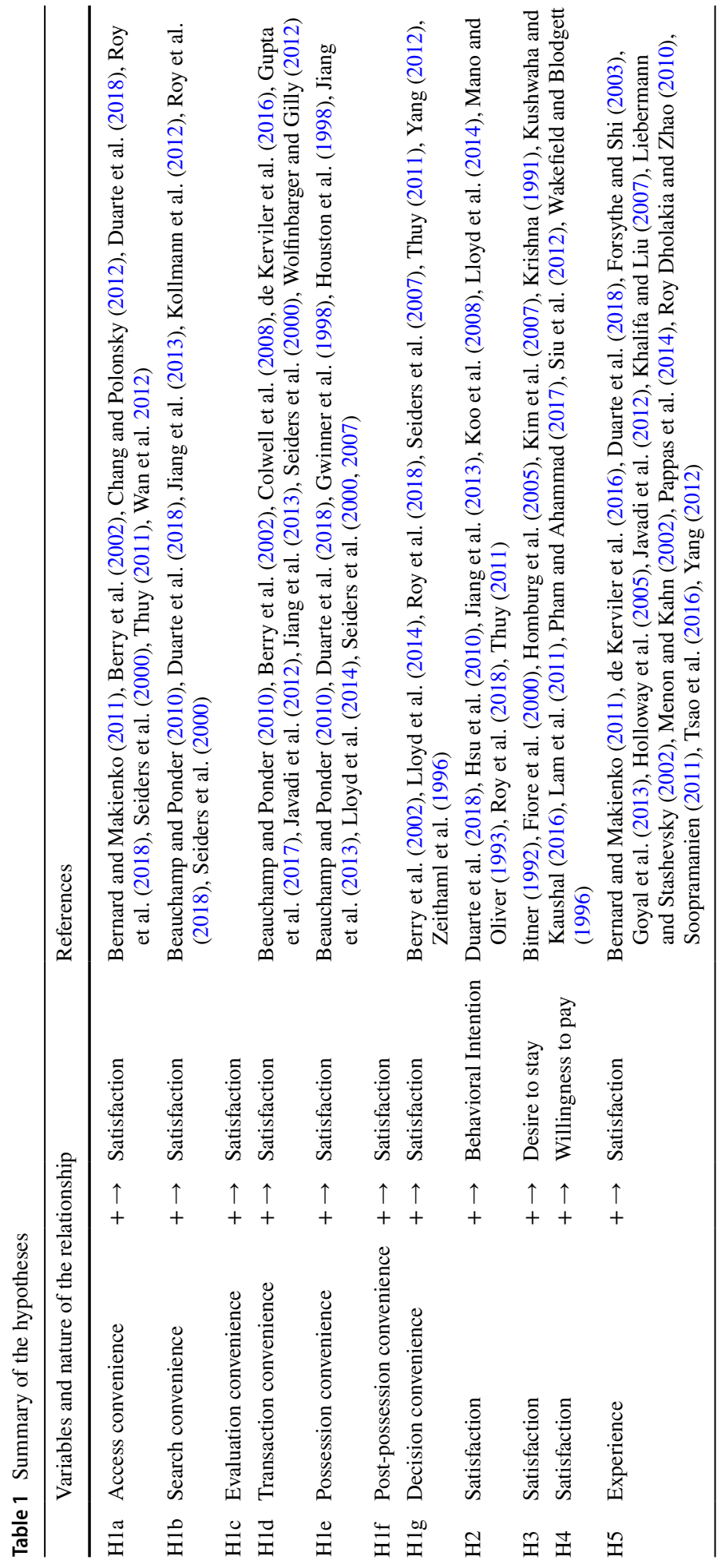




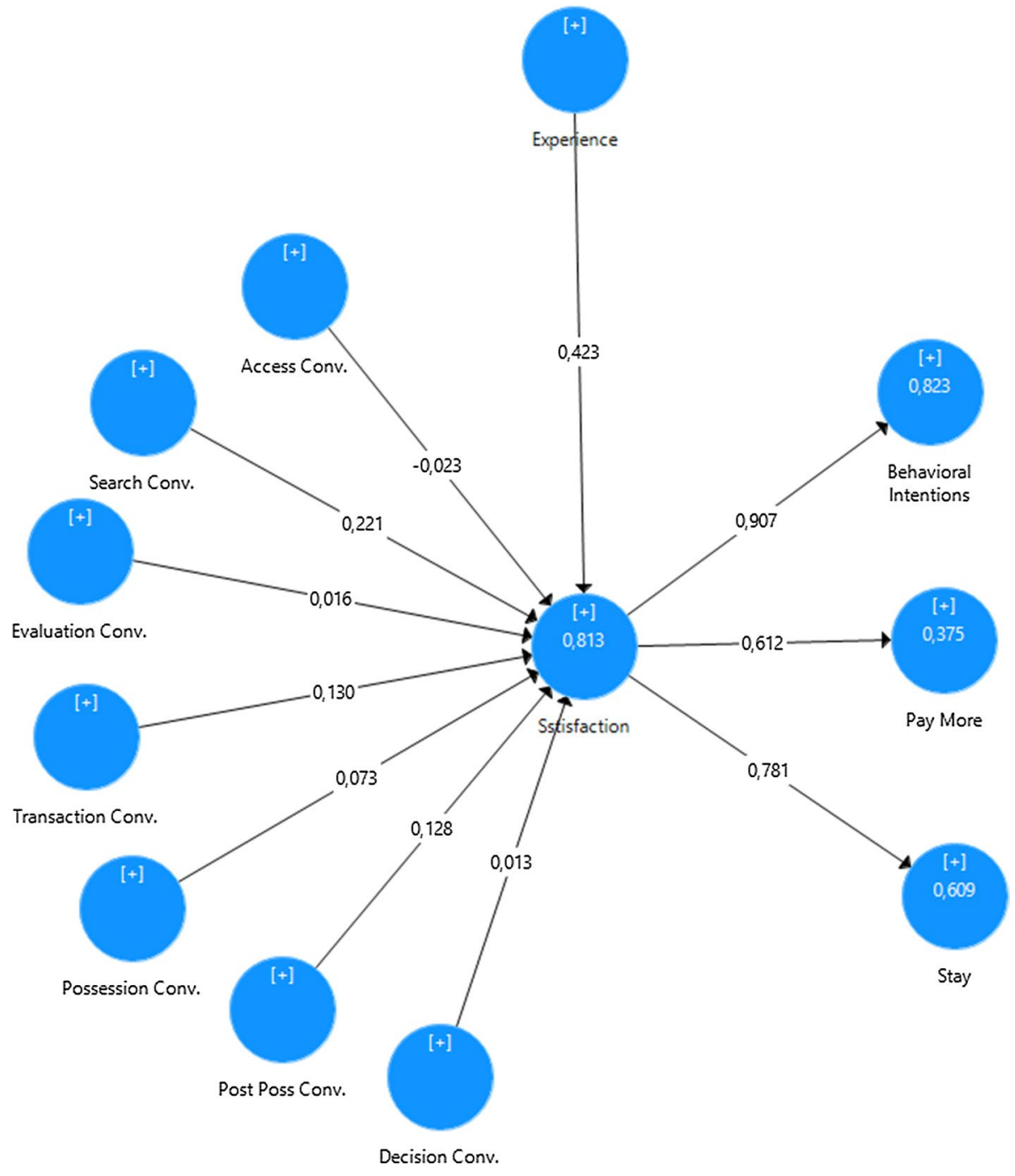

Fig. 1 Results for the research model

the warranty or guaranty" and "I do not bother to pay more make sure product includes insurance facility"). The scales for other constructs were borrowed from previously validated multi-item reflective scales. The measurement items for service convenience (access; search; evaluation; transaction; possession; post-possession; decision) was adapted from Beauchamp and Ponder (2010), Jiang et al. (2013), Colwell et al. (2008), and Seiders et al. (2007). Customer satisfaction items were adapted from Khalifa and Liu (2007) and Colwell et al. (2008). Behavioral intention items were derived from Hsu et al. (2006), Jiang et al. (2013), and Khalifa and Liu (2007). The items for willingness to pay more were copied from Fathi et al. (2016) and the desire to stay items came from Baker and Wakefield (1998). Finally, online experience items were sourced from Chiu 
et al. (2009) and de Kerviler et al. (2016). The details on the measures are reported in Table 2. All items were evaluated using a seven-point Likert scale anchored in 1 representing "strongly disagree" and 7 "strongly agree".

\subsection{Sample}

The form was distributed among university students, non-academic staff, and faculty staff and posted in online forums. Respondents were asked to participate voluntarily, so no reward was offered for the contribution. The survey was deployed using the snowball technique in which individuals are asked to share the survey among their contacts. A total of 235 responses were obtained but 9 responses were eliminated since the respondents had not made online purchases in the last 6 months. The final sample is composed of 226 valid responses. The respondents were 58\% females and $42 \%$ males, mostly aged between 20 and 30 years old $(73.9 \%)$, almost all $(94.2 \%)$ holding a college degree.

\section{Results}

The analysis of the proposed model was conducted using a two-step approach. Firstly, the measurement model is assessed using the Partial Least Squares-path modeling technique (PLS-Path) through SmartPLS 3.2.1 (Ringle et al. 2015) to confirm the quality of the measures. After assuring the quality of the measures, in the second step, the structural model is evaluated.

\subsection{Measurement model evaluation}

To assess the measurement model for reflective constructs, indicators individual contribution, composite reliability, constructs validity, and discriminant validity should be confirmed. Table 2 shows that all constructs present adequate internal consistency, as well as satisfactory levels of Average Variance Extracted (AVE) above the recommended threshold of 0.5. Considering the guidelines by Hulland (1999) the indicators with loadings above 0.7 are acceptable. The results show that all factor loadings except one comply with the 0.7 threshold. Since multicollinearity may create unstable solutions the variance inflation factor (VIF) test was performed. The results show that only 5 constructs were slightly high the more conservative benchmark of 5, however well below the less conservative limit of 10 .

To assess discriminant validity two approaches were considered: the Fornell-Larcker criterion and the Heterotrait-Monotrait Ratio (HTMT). Table 3 shows that despite some minor violations the majority of the constructs present satisfactory discriminant validity.

Likewise, the Heterotrait-Monotrait Ratio (HTMT) of correlation analysis (Henseler et al. 2015) (Table 4) shows that some of the values exceed to predefined threshold of 0.9 . Despite small violations that will impose additional care to the interpretation of the findings, the measurement model reveals adequate quality for carrying on the second phase of the analysis, the structural model evaluation.

\subsection{Structural model analysis}

Figure 1 graphically presents the model path coefficients. 


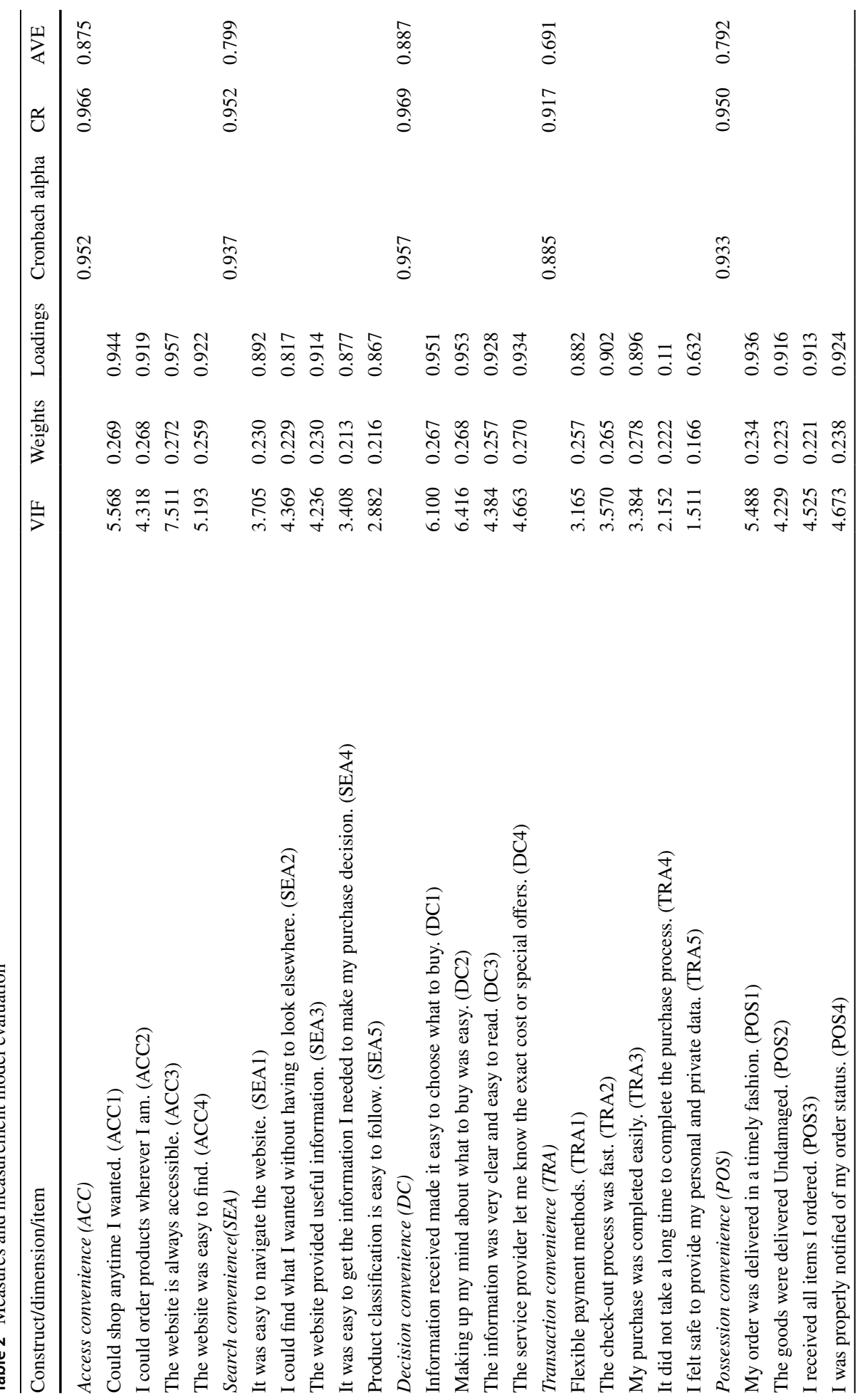




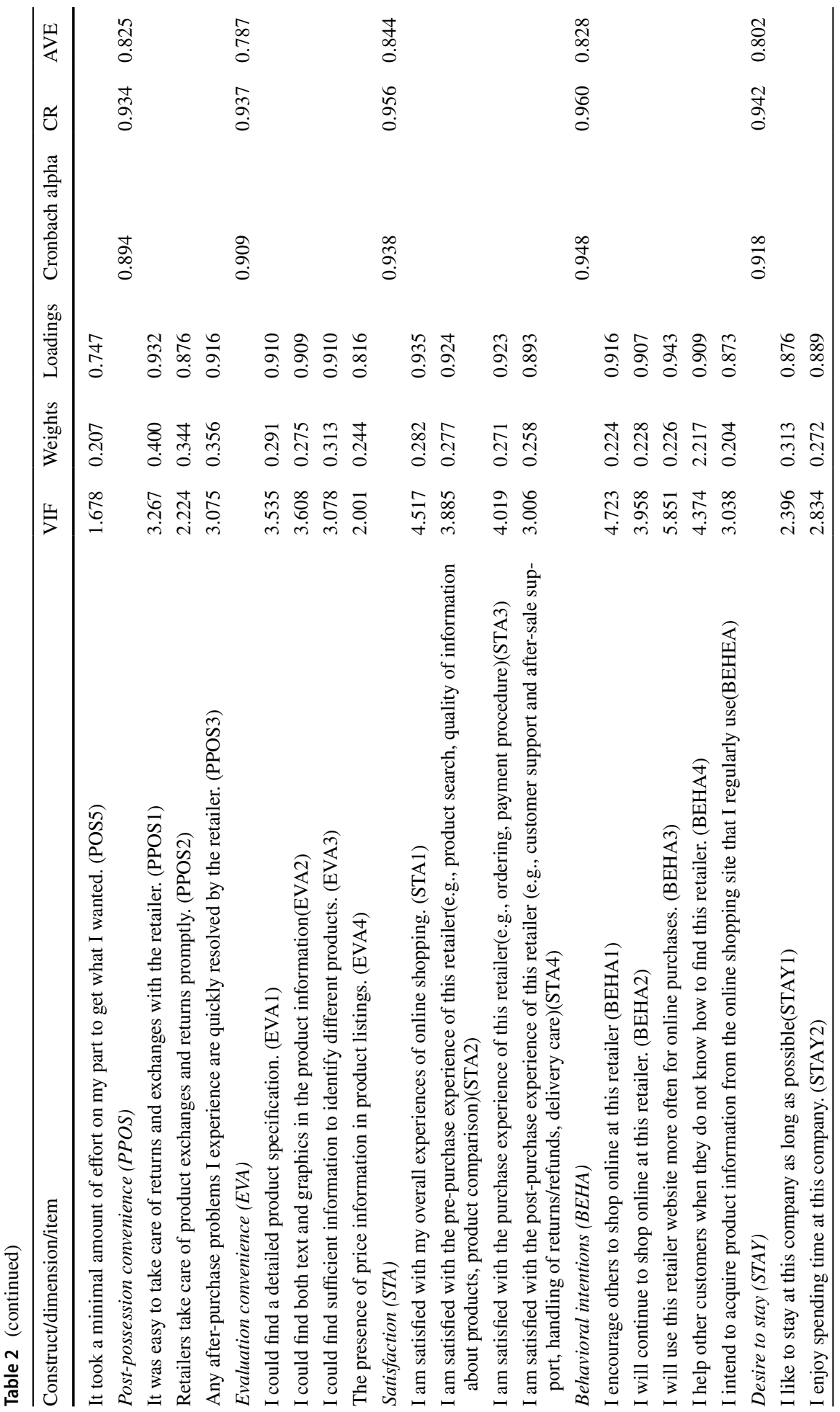




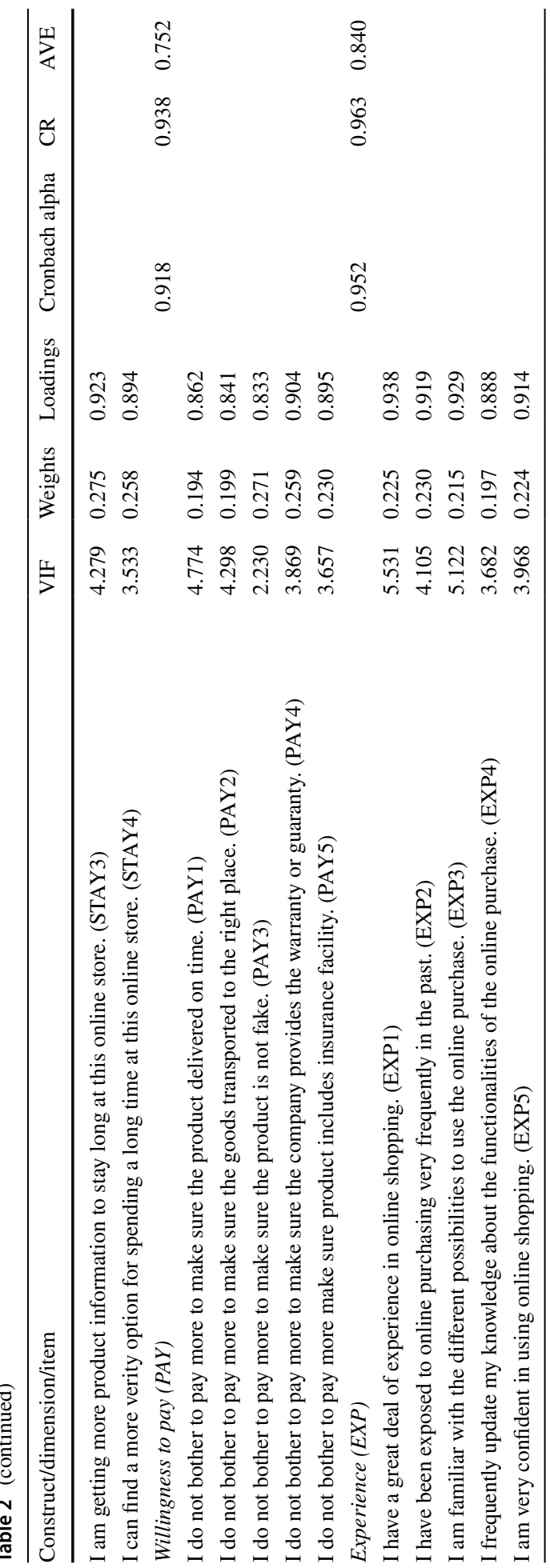


Table 3 Discriminant validity

\begin{tabular}{lllllllllllll}
\hline Construct & ACC & BEHA & DC & EVA & EXP & PAY & POS & PPOS & SEA & SAT & STAY & TRA \\
\hline ACC & $\mathbf{0 . 9 3 6}$ & & & & & & & & & & & \\
BEHA & 0.773 & $\mathbf{0 . 9 1 0}$ & & & & & & & & & & \\
DC & 0.788 & 0.815 & $\mathbf{0 . 9 4 2}$ & & & & & & & & & \\
EVA & 0.739 & 0.755 & 0.824 & $\mathbf{0 . 8 8 7}$ & & & & & & & & \\
EXP & 0.706 & 0.839 & 0.783 & 0.740 & $\mathbf{0 . 9 1 7}$ & & & & & & & \\
PAY & 0.517 & 0.598 & 0.592 & 0.523 & 0.672 & $\mathbf{0 . 8 6 7}$ & & & & & & \\
POS & 0.844 & 0.833 & 0.881 & 0.799 & 0.770 & 0.546 & $\mathbf{0 . 8 9 0}$ & & & & & \\
PPOS & 0.691 & 0.738 & 0.796 & 0.743 & 0.734 & 0.537 & 0.826 & $\mathbf{0 . 9 0 8}$ & & & & \\
SEA & 0.875 & 0.808 & 0.850 & 0.882 & 0.758 & 0.560 & 0.863 & 0.746 & $\mathbf{0 . 8 9 4}$ & & & \\
SAT & 0.749 & 0.907 & 0.807 & 0.783 & 0.847 & 0.612 & 0.819 & 0.778 & 0.820 & $\mathbf{0 . 9 1 9}$ & & \\
STAY & 0.591 & 0.821 & 0.652 & 0.646 & 0.770 & 0.638 & 0.648 & 0.622 & 0.662 & 0.781 & $\mathbf{0 . 8 9 6}$ & \\
TRA & 0.816 & 0.817 & 0.864 & 0.850 & 0.766 & 0.562 & 0.905 & 0.825 & 0.873 & 0.826 & 0.638 & $\mathbf{0 . 8 3 1}$ \\
\hline
\end{tabular}

The square root of the average variance extracted (AVE) is reported in bold between on the main diagonal $A C C$ access convenience, BEHA behavioral intentions, $D C$ decision convenience, EVA evaluation convenience, EXP experience, $P A Y$ willingness to pay, $P O S$ possession convenience, $P P O S$ post-possession convenience, $S E A$ search convenience, $S A T$ satisfaction, $S T A Y$ desire to stay; TRA transaction convenience

Table 4 Heterotrait-monotrait ratio (HTMT)

\begin{tabular}{|c|c|c|c|c|c|c|c|c|c|c|c|c|}
\hline Construct & $\mathrm{ACC}$ & BEHA & $\mathrm{DC}$ & EVA & EXP & PAY & POS & PPOS & SEA & SAT & STAY & TRA \\
\hline \multicolumn{13}{|l|}{$\mathrm{ACC}$} \\
\hline BEHA & 0.812 & & & & & & & & & & & \\
\hline DC & 0.824 & 0.855 & & & & & & & & & & \\
\hline EVA & 0.789 & 0.808 & 0.881 & & & & & & & & & \\
\hline EXP & 0.738 & 0.879 & 0.817 & 0.791 & & & & & & & & \\
\hline PAY & 0.532 & 0.628 & 0.616 & 0.555 & 0.708 & & & & & & & \\
\hline POS & 0.892 & 0.885 & 0.932 & 0.867 & 0.814 & 0.572 & & & & & & \\
\hline PPOS & 0.746 & 0.800 & 0.859 & 0.821 & 0.792 & 0.581 & 0.905 & & & & & \\
\hline SEA & 0.925 & 0.855 & 0.897 & 0.952 & 0.799 & 0.587 & 0.922 & 0.811 & & & & \\
\hline SAT & 0.790 & 0.960 & 0.850 & 0.842 & 0.894 & 0.647 & 0.875 & 0.848 & 0.873 & & & \\
\hline STAY & 0.626 & 0.875 & 0.691 & 0.699 & 0.819 & 0.691 & 0.696 & 0.682 & 0.708 & 0.836 & & \\
\hline TRA & 0.867 & 0.879 & 0.932 & 0.938 & 0.825 & 0.608 & 0.992 & 0.925 & 0.946 & 0.896 & 0.697 & \\
\hline
\end{tabular}

$A C C$ access convenience, $B E H A$ behavioral intentions, $D C$ decision convenience, $E V A$ evaluation convenience, EXP experience, $P A Y$ willingness to pay, $P O S$ possession convenience, $P P O S$ post-possession convenience, $S E A$ search convenience, SAT satisfaction, STAY desire to stay, TRA transaction convenience

Looking at the direct effect (Table 5) it is possible to notice that post-possession convenience $(0.0128, t=2.114, p=0.035)$, search convenience $(0.221, t=2.237$, $p=0.025)$, and experience $(0.423, t=5.307, p=0.000)$ have a positive effect on satisfaction thus confirming $\mathrm{H}_{1 \mathrm{f}}, \mathrm{H}_{1 \mathrm{~b}}$, and $\mathrm{H}_{5}$. For its turn, satisfaction presents a positive impact on behavioral intention $(0.907, t=55.410, p=0.000)$, willingness to pay more (0.612, $t=10.987, p=0.000)$, and desire to stay $(0.781, t=17.391, p=0.000)$ therefore 
confirming $\mathrm{H}_{2}, \mathrm{H}_{3}$, and $\mathrm{H}_{4}$. However, opposite to the initial predictions access convenience $(0.023, t=0.304, \mathrm{p}=0.761)\left(\mathrm{H}_{1 \mathrm{a}}\right)$, evaluation convenience $(0.016, t=0.230$, $p=0.818)\left(\mathrm{H}_{1 \mathrm{c}}\right)$, transaction convenience $(0.130, t=1.468, p=0.142)\left(\mathrm{H}_{1 \mathrm{~d}}\right)$, possession convenience $(0.073, t=0.651, p=0.515)\left(\mathrm{H}_{1 \mathrm{e}}\right)$, decision convenience $(0.013, t=0.157$, $p=0.875)\left(\mathrm{H}_{1 \mathrm{~g}}\right)$ does not present a significant direct impact on satisfaction.

The results (Table 5) show that experience has a significant positive effect on the relationship between all the components of service convenience and customer satisfaction $(0.423, t=5.307, p=0.000)$, supporting $\mathrm{H}_{5}$. Hypothesis six $\left(\mathrm{H}_{6}\right)$ predicts that customer satisfaction has a positive effect on behavioral intention when the online experience is high. Table 6 confirms the result $(t=5.239, p=0.000)$ and consequently, $\mathrm{H}_{6}$ is supported. Table 6 also shows that experience has a significant positive effect on the relationship between customer satisfaction and willingness to pay $(t=4.693, t=0.000)$ supporting $\mathrm{H}_{7}$, a major positive impact on the relationship between customer satisfaction and the desire to stay $(t=4.811, p=0.000)\left(\mathrm{H}_{8}\right)$.

Following the guidelines by Cohen (1988), it can be concluded that experience $\left(f^{2}=0.314\right)$ has a medium effect size on customer satisfaction and for the satisfaction to behavioral intention $\left(f^{2}=4.654\right)$, willingness to pay $\left(f^{2}=0.600\right)$ and desire to stay $\left(f^{2}=1.559\right)$ had a large effect. The remaining relationship can be interpreted as having small effects.

Furthermore, results confirm the indirect effects of search convenience $(t=2.233$, $p=0.026)$, post-possession convenience $(t=2.121, p=0.034)$ and experience $(t=5.239$, $p=0.000$ ) on the behavioral intention, pay more and stay through satisfaction (Table 6).

Table 7 shows the path coefficient values and statistical significance, and variance explained $\left(R^{2}\right)$ for endogenous constructs.

Models with a good fit should have a Standardized Root Mean Square Residual (SRMR) less than 0.10 being values under 0.08 desirable. As shown in Table 8 model presented an SRMR of 0.062, which indicates a good fit.

Table 5 Effects on endogenous variables (direct effect)

\begin{tabular}{|c|c|c|c|c|c|c|c|c|}
\hline \multicolumn{4}{|c|}{$\begin{array}{l}\text { Direct effect on endogenous variables } \\
\text { (hypotheses) }\end{array}$} & \multirow{2}{*}{$\begin{array}{l}\text { Direct effect } \\
0.023\end{array}$} & \multirow{2}{*}{$\begin{array}{c}t \text { statistic } \\
0.304\end{array}$} & \multirow{2}{*}{$\begin{array}{l}p \text { values } \\
0.761\end{array}$} & \multirow{2}{*}{$\begin{array}{l}f^{2} \\
0.001\end{array}$} & \multirow{2}{*}{$\begin{array}{l}\begin{array}{l}\text { Hypothesis } \\
\text { validation }\end{array} \\
\text { Not supported }\end{array}$} \\
\hline Access Conv & H1a & $\rightarrow$ & Satisfaction & & & & & \\
\hline Search Conv & $\mathrm{H} 1 \mathrm{~b}$ & $\rightarrow$ & Satisfaction & 0.221 & 2.237 & 0.025 & 0.027 & Supported \\
\hline Evaluation Conv & $\mathrm{H} 1 \mathrm{c}$ & $\rightarrow$ & Satisfaction & 0.016 & 0.230 & 0.818 & 0.000 & Not supported \\
\hline $\begin{array}{l}\text { Transaction } \\
\text { Conv }\end{array}$ & H1d & $\rightarrow$ & Satisfaction & 0.130 & 1.468 & 0.142 & 0.011 & Not supported \\
\hline Possession Conv & H1e & $\rightarrow$ & Satisfaction & 0.073 & 0.651 & 0.515 & 0.003 & Not supported \\
\hline Post Poss Conv & H1f & $\rightarrow$ & Satisfaction & 0.128 & 2.114 & 0.035 & 0.023 & Supported \\
\hline Decision Conv & $\mathrm{H} 1 \mathrm{~g}$ & $\rightarrow$ & Satisfaction & 0.013 & 0.157 & 0.875 & 0.000 & Not supported \\
\hline Satisfaction & $\mathrm{H} 2$ & $\rightarrow$ & $\begin{array}{l}\text { Behav. inten- } \\
\text { tions }\end{array}$ & 0.907 & 55.410 & 0.000 & 4.654 & Supported \\
\hline Satisfaction & $\mathrm{H} 3$ & $\rightarrow$ & Stay & 0.781 & 17.931 & 0.000 & 1.559 & Supported \\
\hline Satisfaction & $\mathrm{H} 4$ & $\rightarrow$ & Pay more & 0.612 & 10.987 & 0.000 & 0.600 & Supported \\
\hline Experience & H5 & $\rightarrow$ & Satisfaction & 0.423 & 5.307 & 0.000 & 0.314 & Supported \\
\hline
\end{tabular}

$t$ (4999) one-tailed test based on bootstrap procedure with 5000 resamples; $p<.05$ 
Table 6 Indirect effects on endogenous variables

\begin{tabular}{|c|c|c|c|c|c|c|c|}
\hline \multicolumn{3}{|c|}{ Indirect effects on endogenous variables } & \multirow{2}{*}{$\begin{array}{l}\text { Original sample } \\
-0.020\end{array}$} & \multirow{2}{*}{$\begin{array}{l}\text { Sample mean } \\
-0.023\end{array}$} & \multirow{2}{*}{$\begin{array}{l}\begin{array}{l}\text { Standard } \\
\text { deviation }\end{array} \\
0.067\end{array}$} & \multirow{2}{*}{$\begin{array}{l}t \text {-statistic } \\
0.304\end{array}$} & \multirow{2}{*}{$\begin{array}{l}p \text { values } \\
0.761\end{array}$} \\
\hline Access Conv & $\rightarrow$ & $\begin{array}{l}\text { Behavioral } \\
\text { intentions }\end{array}$ & & & & & \\
\hline Access Conv & $\rightarrow$ & Pay more & -0.014 & -0.016 & 0.046 & 0.303 & 0.762 \\
\hline Access Conv & $\rightarrow$ & Stay & -0.018 & -0.020 & 0.058 & 0.304 & 0.761 \\
\hline Decision Conv & $\rightarrow$ & $\begin{array}{l}\text { Behavioral } \\
\text { intentions }\end{array}$ & 0.012 & 0.008 & 0.077 & 0.157 & 0.875 \\
\hline Decision Conv & $\rightarrow$ & Pay more & 0.008 & 0.006 & 0.052 & 0.156 & 0.876 \\
\hline Decision Conv & $\rightarrow$ & Stay & 0.010 & 0.007 & 0.066 & 0.157 & 0.875 \\
\hline Evaluation Conv & $\rightarrow$ & $\begin{array}{l}\text { Behavioral } \\
\text { intentions }\end{array}$ & 0.015 & 0.011 & 0.065 & 0.230 & 0.818 \\
\hline Evaluation Conv & $\rightarrow$ & Pay more & 0.010 & 0.007 & 0.044 & 0.229 & 0.819 \\
\hline Evaluation Conv & $\rightarrow$ & Stay & 0.013 & 0.009 & 0.056 & 0.229 & 0.819 \\
\hline Experience & $\rightarrow$ & $\begin{array}{l}\text { Behavioral } \\
\text { intentions }\end{array}$ & 0.384 & 0.385 & 0.073 & 5.239 & 0.000 \\
\hline Experience & $\rightarrow$ & Pay more & 0.259 & 0.260 & 0.055 & 4.693 & 0.000 \\
\hline Experience & $\rightarrow$ & Stay & 0.331 & 0.332 & 0.069 & 4.811 & 0.000 \\
\hline Possession Conv & $\rightarrow$ & $\begin{array}{l}\text { Behavioral } \\
\text { intentions }\end{array}$ & 0.066 & 0.076 & 0.101 & 0.651 & 0.515 \\
\hline Possession Conv & $\rightarrow$ & Pay more & 0.045 & 0.051 & 0.069 & 0.647 & 0.517 \\
\hline Possession Conv & $\rightarrow$ & Stay & 0.057 & 0.065 & 0.087 & 0.650 & 0.516 \\
\hline Post Poss Conv & $\rightarrow$ & $\begin{array}{l}\text { Behavioral } \\
\text { intentions }\end{array}$ & 0.116 & 0.115 & 0.055 & 2.121 & 0.034 \\
\hline Post Poss Conv & $\rightarrow$ & Pay more & 0.078 & 0.077 & 0.037 & 2.093 & 0.036 \\
\hline Post Poss Conv & $\rightarrow$ & Stay & 0.100 & 0.099 & 0.048 & 2.103 & 0.036 \\
\hline Search Conv & $\rightarrow$ & $\begin{array}{l}\text { Behavioral } \\
\text { intentions }\end{array}$ & 0.200 & 0.202 & 0.090 & 2.233 & 0.026 \\
\hline Search Conv & $\rightarrow$ & Pay more & 0.135 & 0.136 & 0.062 & 2.165 & 0.030 \\
\hline Search Conv & $\rightarrow$ & Stay & 0.172 & 0.174 & 0.078 & 2.209 & 0.027 \\
\hline $\begin{array}{l}\text { Transaction } \\
\text { Conv }\end{array}$ & $\rightarrow$ & $\begin{array}{l}\text { Behavioral } \\
\text { intentions }\end{array}$ & 0.118 & 0.118 & 0.080 & 1.471 & 0.141 \\
\hline $\begin{array}{l}\text { Transaction } \\
\text { Conv }\end{array}$ & $\rightarrow$ & Pay more & 0.080 & 0.080 & 0.055 & 1.454 & 0.146 \\
\hline $\begin{array}{l}\text { Transaction } \\
\text { Conv }\end{array}$ & $\rightarrow$ & Stay & 0.102 & 0.101 & 0.069 & 1.474 & 0.141 \\
\hline
\end{tabular}

$t(4999)$ one-tailed test based on bootstrap procedure with 5000 resamples; $p<.05$

\section{Discussion and implications}

This study empirically examines the direct effect of service convenience on satisfaction, and the link between satisfaction and behavioral intention, willingness to pay, and desire to stay. Prior research that examined convenience has mostly focused on the association with consumer satisfaction, behavioral intentions, and word-of-mouth (Jiang et al. 2013). The current study added new outcomes such as willingness to pay and desire to stay. Besides, this article also verified the moderating effect of experience on the relationship of service 
Table $7 R$ square for endogenous constructs

\begin{tabular}{llllrl}
\hline Constructs & $R^{2}$ & Sample mean & $\begin{array}{l}\text { Standard } \\
\text { deviation }\end{array}$ & $t$-statistics & $p$ values \\
\hline Behavioral intentions & 0.823 & 0.823 & 0.030 & 27.812 & 0.000 \\
Pay more & 0.375 & 0.378 & 0.068 & 5.541 & 0.000 \\
Satisfaction & 0.813 & 0.821 & 0.035 & 23.534 & 0.000 \\
Stay & 0.609 & 0.612 & 0.067 & 9.042 & 0.000 \\
\hline
\end{tabular}

Table 8 Goodness of fit criteria

\begin{tabular}{lcc}
\hline Fit criteria & Saturated model & Estimated model \\
\hline SRMR & 0.062 & 0.071 \\
$\mathrm{D}_{\text {ULS }}$ & 5.429 & 7.155 \\
$\mathrm{D}_{\text {G }}$ & 3.065 & 3.234 \\
Chi-Square & 3582.127 & 3720.624 \\
NFI & 0.789 & 0.780 \\
\hline
\end{tabular}

HI95 $=95 \%$ of bootstrap quantile. Model assessment criteria: SRMR $<95 \%$ of bootstrap quantile (HI95 of SRMR), $\mathrm{D}_{\mathrm{ULS}}<95 \%$ of bootstrap quantile (HI95 of $\mathrm{d}_{\mathrm{ULS}}$ ) and $\mathrm{d}_{\mathrm{G}}<95 \%$ of bootstrap quantile (HI95 of $\mathrm{d}_{\mathrm{G}}$ )

convenience with customer satisfaction, as well as customer satisfaction with behavioral intention, willingness to pay more, and desire to stay.

The results for $\mathrm{H}_{1 \mathrm{~b}, \mathrm{f}}$ indicate that search and post-possession convenience influence customer satisfaction in the Chinese customer perspective. This result is also supported by previous studies (Jiang et al. 2013) for online shoppers in Hong Kong, suggesting that Chinese customers value more the aspects of convenience outcome (search and post-possession). The fact that it can save time and effort physically visiting various locations to locate their desired product and most online retailers in China rigid return guaranteed only permit exchange. Access, evaluation, transaction, possession, and decision convenience $\left(\mathrm{H}_{1 \mathrm{a}, \mathrm{c}, \mathrm{d}, \mathrm{e}, \mathrm{g}}\right)$ do not suggest a significant effect on customer satisfaction through behavior intention, willingness to pay more, and desire to stay. Being this a puzzling result, the authors questioned a small number of Chinese online shoppers just to shed some light on the results. The interviews indicated that customers already enjoyed the benefits of online activities and online retailers offering detailed product specification and easy evaluation already established. After purchasing the online payment method is convenient and simple, whole check out process takes less than minutes and customer can easily notify the order status of the product which convenience making easy to take decision what to buy. This would be explaining why Chinese online customers more advanced aspects of service convenience and insignificant influence upon satisfaction. These interesting findings are similar to Chang and Polonsky (2012) and Duarte et al. (2018) who found that decision, access, search and transaction convenience did not influence customer satisfaction. In fact, Duarte et al. (2018) established a relation between evaluation and customer satisfaction. The findings confirmed that online experience moderates the relationship of service convenience with customer satisfaction (H5). Based on these findings it is possible to state that more experienced customers are better prepared to evaluate the benefits and risk of the product or service. 


\subsection{Theoretical implications}

From a theoretical point of view, the current study fills several gapes. The studies extend the previous work on the associations to service convenience by verifying the meaningful impact of online shopping convenience on customer satisfaction and behavioral intention, which reveal the further importance of an effect on the willingness to pay more and desire to stay. We included a new antecedent of decision convenience which extending the lead into a willingness to pay and desire to stay. The result of this study indicates that customer satisfaction had a strong direct effect on behavioral intention. These results confirm Seiders et al. (2007). Furthermore, customer satisfaction had a strong direct effect on willingness to pay and desire to say. These results also confirm by Pham and Ahammad, (2017) and Siu et al. (2012).

Moreover, this study reassesses the framework proposed by Duarte et al. (2018) by testing with a new sample the different levels of online convenience influence customer satisfaction, behavioral intention; and extends it by considering the moderating effect of online experience filling the gap raised by the fragmented research done on this topic. Pappas et al. (2014) had already examined the power of experience on satisfaction, intention to repurchase, and found a significant effect of online experience on customer satisfaction and repurchase intention. However, they miss studying the effect of customer satisfaction on behavioral intention, willingness to pay, and desire to stay which was investigated by Lam et al. (2011) and Siu et al. (2012) but they do not examine the moderating effect of the online experience.

Online experience shows the strongest effect on satisfaction and behavioral intention. This result supports Venkatesh et al. (2003) who investigated the moderating effect of experience on behavioral intention, although they used different antecedents. The relationship between online customer satisfaction and willingness to pay is stronger when the experience is high. Findings suggest that satisfied customers willing to pay more, this result consistent with Pham and Ahammad (2017). Similarly, a significant effect was found between customer satisfaction and the desire to stay and online experience. This may be elucidated by the reality that experience customers might be expected to convey a greater desire to stay rather than those who are less experienced online shopping.

\subsection{Managerial implications}

The current findings also have interesting insights for online retail managers. Firms need to understand that experience customers are more sensitive to their decision than inexperienced customers (Cheema and Papatla 2010) and the findings confirm that online experience effect of service convenience on customer satisfaction. The results establish that online experience has a stronger effect on satisfaction, behavioral intention, willingness to pay more, and desire to stay online store. Thus, companies should develop, and support actions aimed at increasing the online experience of individuals. Positive feelings toward online shopping experience are more intense if online retailers offer competitive prices, flexible payment methods, on-time delivery, quick purchase process, and user-friendly website, which can influence and impact their behavioral intention, willingness to pay, and desire to stay. Based on the findings it is recommended that online retailers should be the aware of the effect of these factors to attract inexperienced customers and increase the satisfaction of current consumers to nurture their willingness to pay more and loyalty. Finally, 
considering that measuring sustainability performance has become increasingly important for firms (Rajesh 2020b; Rajesh and Rajendran 2020) the current findings are particularly important for the companies committed to reducing their carbon footprint in understanding how they can use online convenience to stimulate online purchases among their clients and consequently becoming more environmentally friendly and socially responsible.

\section{Limitations and future research}

One comprehensible limitation of this study is the small size of the sample. Although the authors tried to reach maximum respondents from different areas in China, the feedback was poor, and many respondents were students. Future studies should consider addressing these limitations by increasing the sample size allowing for more robust conclusions. Also, data are limited to customers in China, so future studies could also examine the effects in other fast-growing online shopping markets to validate the current findings.

The measurement of the SCV, access convenience, transaction convenience, evaluation convenience, possession convenience, and decision convenience may be improved, as better measures could lead to different results for sub hypotheses of H1. Therefore, future research could use more precise instruments to measure these five dimensions of convenience. The current investigation did not use demographic variables in the model, however, it will be important to asses them in future researches with larger samples. It is expected that future studies may address this limitation. Moreover, since this study addressed online shopping in general, future research could compare the results using a multigroup approach based on the type of company or product as well as focusing on real behavioral outcomes rather than consumer intentions.

Lastly, according to the current results, search convenience and post-possession convenience display a significant influence on customer satisfaction, thus several research questions deserve further investigation, for instance: does adopt a "post-possession convenience" and "search convenience" based strategy will improve performance in emerging markets? Which characteristics should a company fulfill to effectively use such the SCV approach? Which ones would be more effective in reducing environmental footprint and more likely to improve the firm's reputation from the consumer point of view?

\section{References}

Aagja, J. P., Mammen, T., \& Saraswat, A. (2011). Validating service convenience scale and profiling customers: A study in the indian retail context. Vikalpa. https://doi.org/10.1177/0256090920110403.

Ameer, I. A. (2013). Satisfaction-A behavioral perspective on consumer: Review, criticism and contribution. International Journal of Research Studies in Management. https://doi.org/10.5861/ijrsm .2013.406.

Baker, J., \& Wakefield, K. L. (1998). Excitement at the mall: Determinants and effects on shopping response. Journal of Retailing, 74(4), 515-539.

Beauchamp, M., \& Bednarz, N. (2010). Perceptions of retail convenience for in-store and online shoppers. Marketing Management Journal, 20(1), 49-65.

Beauchamp, M. B., \& Ponder, N. (2010). Perception of retail convenience for in-store and online shoppers. Marketing Management Journal, 20(1), 49-65.

Benoit, S., Klose, S., \& Ettinger, A. (2017). Linking service convenience to satisfaction: Dimensions and key moderators. Journal of Services Marketing, 31(6), 527-538. https://doi.org/10.1108/ JSM-10-2016-0353. 
Bernard, E. K., \& Makienko, I. (2011). The effects of information privacy and online shopping experience in E-commerce. Academy of Marketing Studies Journal, 15(1 SI), 97-112.

Berry, L. L., Seiders, K., \& Grewal, D. (2002). Understanding service convenience. Journal of Marketing, 66(3), 1-17. https://doi.org/10.1509/jmkg.66.3.1.18505.

Bertram, R. F., \& Chi, T. (2018). A study of companies' business responses to fashion e-commerce's environmental impact. International Journal of Fashion Design, Technology and Education, 11(2), 254-264. https://doi.org/10.1080/17543266.2017.1406541.

Bhatnagar, A., Misra, S., \& Rao, H. R. (2000). On risk, convenience, and Internet shopping behavior. Communications of the ACM, 43(11), 98-105. https://doi.org/10.1145/353360.353371.

Bitner, M. J. (1992). Servicescapes: The impact of physical surroundings on customers and employees. Journal of Marketing, 56(2), 57-71. https://doi.org/10.1177/002224299205600205.

Brown, L. G. (1990). Convenience in services marketing. Journal of Services Marketing, 4(1), 53-59. https://doi.org/10.1108/EUM0000000002505.

Cameron, T. A., \& James, M. D. (1987). Estimating willingness to pay from survey data: An alternative pre-test-market evaluation procedure. Journal of Marketing Research, 24(4), 389-395. https://doi. org/10.1177/002224378702400406.

Chang, Y. W., \& Polonsky, M. J. (2012). The influence of multiple types of service convenience on behavioral intentions: The mediating role of consumer satisfaction in a Taiwanese leisure setting. International Journal of Hospitality Management, 31(1), 107-118. https://doi.org/10.1016/j. ijhm.2011.05.003.

Cheema, A., \& Papatla, P. (2010). Relative importance of online versus offline information for Internet purchases: Product category and Internet experience effects. Journal of Business Research, 63(910), 979-985. https://doi.org/10.1016/j.jbusres.2009.01.021.

Chen, Y. C., Shang, R. A., \& Kao, C. Y. (2009). The effects of information overload on consumers' subjective state towards buying decision in the internet shopping environment. Electronic Commerce Research and Applications, 8(1), 48-58. https://doi.org/10.1016/j.elerap.2008.09.001.

Chiu, C. M., Lin, H. Y., Sun, S. Y., \& Hsu, M. H. (2009). Understanding customers' loyalty intentions towards online shopping: An integration of technology acceptance model and fairness theory. Behaviour and Information Technology. https://doi.org/10.1080/01449290801892492.

Cohen, J. (1988). Statistical power analysis for the behavioral sciences. Mahwah: L. Erlbaum Associates.

Colwell, S. R., Aung, M., Kanetkar, V., \& Holden, A. L. (2008). Toward a measure of service convenience: Multiple-item scale development and empirical test. Journal of Services Marketing, 22(2), 160-169. https://doi.org/10.1108/08876040810862895.

Dabholkar, P. A. (1996). Consumer evaluations of new technology-based self-service options: An investigation of alternative models of service quality. International Journal of Research in Marketing, 13(1), 29-51.

de Kerviler, G., Demoulin, N. T. M., \& Zidda, P. (2016). Adoption of in-store mobile payment: Are perceived risk and convenience the only drivers? Journal of Retailing and Consumer Services, 31, 334-344. https://doi.org/10.1016/j.jretconser.2016.04.011.

Duarte, P., Costa e Silva, S., \& Ferreira, M. B. (2018). How convenient is it? Delivering online shopping convenience to enhance customer satisfaction and encourage e-WOM. Journal of Retailing and Consumer Services, 44(September), 161-169. https://doi.org/10.1016/j.jretconser.2018.06.007.

Edwards, J., McKinnon, A., \& Cullinane, S. (2009). Modelling the environmental impacts of conventional and online non-food shopping. Management.

Edwards, J., McKinnon, A. C., \& Cullinane, S. L. (2010). Comparative analysis of the carbon footprints of conventional and online retailing: A "last mile" perspective. International Journal of Physical Distribution \& Logistics Management, 40(1/2), 103-123. https://doi.org/10.1108/09600031011018055.

Falk, T., Schepers, J., Hammerschmidt, M., \& Bauer, H. H. (2007). Identifying cross-channel dissynergies for multichannel service providers. Journal of Service Research, 10(2), 143-160. https://doi. org/10.1177/1094670507306683.

Farquhar, J. D., \& Rowley, J. (2009). Convenience: A services perspective. Marketing Theory, 9(4), 425-438. https://doi.org/10.1177/1470593109346894.

Fathi, E., Zailani, S., Iranmanesh, M., \& Kanapathy, K. (2016). Drivers of consumers' willingness to pay for halal logistics. British Food Journal, 118(2), 464-479. https://doi.org/10.1108/BFJ-06-2015-0212.

Fiore, A. M., Yah, X., \& Yoh, E. (2000). Effects of a product display and environmental fragrancing on approach responses and pleasurable experiences. Psychology and Marketing, 17(1), 27-54. https:// doi.org/10.1002/(SICI)1520-6793(200001)17:1<27:AID-MAR3>3.0.CO;2-C.

Forsythe, S. M., \& Shi, B. (2003). Consumer patronage and risk perceptions in Internet shopping. Journal of Business Research, 56(11), 867-875. https://doi.org/10.1016/S0148-2963(01)00273-9. 
Frambach, R. T., Roest, H. C. A., \& Krishnan, T. V. (2007). The impact of consumer Internet experience on channel preference and usage intentions across the different stages of the buying process. Journal of Interactive Marketing, 21(2), 26-41. https://doi.org/10.1002/dir.20079.

Giannakos, M. N., Pateli, A. G., \& Pappas, I. O. (2011). Identifying the direct effect of experience and the moderating effect of satisfaction in the greek online market. International Journal of E-Services and Mobile Applications, 3(2), 39-58. https://doi.org/10.4018/jesma.2011040103.

Goyal, A., Maity, M., Thamizhvanan, A., \& Xavier, M. J. (2013). Determinants of customers' online purchase intention: An empirical study in India. Journal of Indian Business Research, 5(1), 17-32. https://doi.org/10.1108/17554191311303367.

Gupta, S., Pansari, A., \& Kumar, V. (2017). Global customer engagement. Journal of International Marketing, 26(1), 4-29. https://doi.org/10.1509/jim.17.0091.

Gwinner, K. P., Gremler, D. D., \& Bitner, M. J. (1998). Relational benefits in services industries: The customer's perspective. Journal of the Academy of Marketing Science, 26(2), 101-114. https://doi. org/10.1177/0092070398262002.

Henseler, J., Ringle, C. M., \& Sarstedt, M. (2015). A new criterion for assessing discriminant validity in variance-based structural equation modeling. Journal of the Academy of Marketing Science, 43(1), 115-135. https://doi.org/10.1007/s11747-014-0403-8.

Holloway, B. B., Wang, S., \& Parish, J. T. (2005). The role of cumulative online purchasing experience in service recovery management. Journal of Interactive Marketing, 19(3), 54-66. https://doi. org/10.1002/dir.20043.

Homburg, C., Koschate, N., \& Hoyer, W. D. (2005). Do satisfied customers really pay more? A study of the relationship between customer satisfaction and willingness to pay. Journal of Marketing, 69(2), 84-96. https://doi.org/10.1509/jmkg.69.2.84.60760.

Houston, M. B., Bettencourt, L. A., \& Wenger, S. (1998). The relationship between waiting in a service queue and evaluations of service quality: A field theory perspective. Psychology and Marketing, 15(8), 735-753.

Hsu, C. L., Chen, M. C., Chang, K. C., \& Chao, C. M. (2010). Applying loss aversion to investigate service quality in logistics: A moderating effect of service convenience. International Journal of Operations and Production Management, 30(5), 508-525. https://doi.org/10.1108/0144357101 1039605.

Hsu, M. H., Yen, C. H., Chiu, C. M., \& Chang, C. M. (2006). A longitudinal investigation of continued online shopping behavior: An extension of the theory of planned behavior. International Journal of Human Computer Studies, 64(9), 889-904. https://doi.org/10.1016/j.ijhcs.2006.04.004.

Hulland, J. (1999). Use of partial least squares (PLS) in strategic management research: a review of four recent studies. Strategic Management Journal, 20(2), 195-204. https://doi.org/10.1002/(SICI)10970266(199902)20:2<195:AID-SMJ13>3.0.CO;2-7.

Javadi, M. H. M., Rezaie Dolatabadi, H., Nourbakhsh, M., Poursaeedi, A., \& Asadollahi, A. R. (2012). An analysis of factors affecting on online shopping behavior of consumers. International Journal of Marketing Studies, 4(5), 81-98.

Jayawardhena, C., Wright, L. T., \& Dennis, C. (2007). Consumers online: Intentions, orientations and segmentation. International Journal of Retail and Distribution Management, 35(6), 515-526.

Jedidi, K., \& Zhang, Z. J. (2002). Augmenting conjoint analysis to estimate consumer reservation price. Management Science, 48(10), 1350-1368. https://doi.org/10.1287/mnsc.48.10.1350.272.

Jiang, L., Yang, Z., \& Jun, M. (2013). Measuring consumer perceptions of online shopping convenience. Journal of Service Management, 24(2), 191-214. https://doi.org/10.1108/09564231311323962.

Jun, M., Yang, Z., \& Kim, D. S. (2004). Customers' perceptions of online retailing service quality and their satisfaction. International Journal of Quality and Reliability Management, 21(8), 817-840. https://doi.org/10.1108/02656710410551728.

Kaura, V. (2013). Service convenience, customer satisfaction, and customer loyalty: study of Indian Commercial Banks. Journal of Global Marketing, 26(1), 18-27. https://doi.org/10.1080/08911 762.2013.779405.

Kaura, V., Durga Prasad, C. S., \& Sharma, S. (2015). Service quality, service convenience, price and fairness, customer loyalty, and the mediating role of customer satisfaction. International Journal of Bank Marketing, 33(4), 404-422. https://doi.org/10.1108/IJBM-04-2014-0048.

Khalifa, M., \& Liu, V. (2007). Online consumer retention: Contingent effects of online shopping habit and online shopping experience. European Journal of Information Systems, 16(6), 780-792. https:// doi.org/10.1057/palgrave.ejis.3000711.

Kim, J., Fiore, A. M., \& Lee, H. H. (2007). Influences of online store perception, shopping enjoyment, and shopping involvement on consumer patronage behavior towards an online retailer. Journal of Retailing and Consumer Services, 14(2), 95-107. https://doi.org/10.1016/j.jretconser.2006.05.001. 
Kollmann, T., Kuckertz, A., \& Kayser, I. (2012). Cannibalization or synergy? Consumers' channel selection in online-offline multichannel systems. Journal of Retailing and Consumer Services, 19(2), 186-194. https://doi.org/10.1016/j.jretconser.2011.11.008.

Koo, D. M., Kim, J. J., \& Lee, S. H. (2008). Personal values as underlying motives of shopping online. Asia Pacific Journal of Marketing and Logistics, 20(2), 156-173. https://doi.org/10.1108/13555 850810864533.

Krishna, A. (1991). Effect of dealing patterns on consumer perceptions of deal frequency and willingness to pay. Journal of Marketing Research, 28(4), 441-451. https://doi.org/10.1177/0022243791 02800406.

Kushwaha, G. S., \& Kaushal, M. (2016). E-satisfaction and E-loyalty. International Journal of Online Marketing, 6(4), 36-53. https://doi.org/10.4018/ijom.2016100103.

Lam, L. W., Chan, K. W., Fong, D., \& Lo, F. (2011). Does the look matter? The impact of casino servicescape on gaming customer satisfaction, intention to revisit, and desire to stay. International Journal of Hospitality Management, 30(3), 558-567. https://doi.org/10.1016/j.ijhm.2010.10.003.

Laroche, M., Yang, Z., McDougall, G. H. G., \& Bergeron, J. (2005). Internet versus bricks-and-mortar retailers: An investigation into intangibility and its consequences. Journal of Retailing, 81(4), 251267. https://doi.org/10.1016/j.jretai.2004.11.002.

Lee, G. G., \& Lin, H. F. (2005). Customer perceptions of e-service quality in online shopping. International Journal of Retail and Distribution Management. https://doi.org/10.1108/095905505105814 85.

Leonard, L. B. (2016). Revisiting "big ideas in services marketing” 30 years later. Journal of Services Marketing, 30(1), 3-6. https://doi.org/10.1108/JSM-10-2015-0318.

Liebermann, Y., \& Stashevsky, S. (2002). Perceived risks as barriers to Internet and e-commerce usage. Qualitative Market Research: An International Journal, 5(4), 291-300. https://doi. org/10.1108/13522750210443245.

Lloyd, A. E., Chan, R. Y. K., Yip, L. S. C., \& Chan, A. (2014). Time buying and time saving: Effects on service convenience and the shopping experience at the mall. Journal of Services Marketing, 28(1), 36-49. https://doi.org/10.1108/JSM-03-2012-0065.

Mano, H., \& Oliver, R. L. (1993). Assessing the dimensionality and structure of the consumption experience: Evaluation, feeling, and satisfaction. Journal of Consumer Research. https://doi.org/10.1086/209361.

Mathiyazhagan, K., Sengupta, S., \& Mathivathanan, D. (2019). Challenges for implementing green concept in sustainable manufacturing: A systematic review. OPSEARCH, 56(1), 32-72. https://doi. org/10.1007/s12597-019-00359-2.

Menon, S., \& Kahn, B. (2002). Cross-category effects of induced arousal and pleasure on the Internet shopping experience. Journal of Retailing. https://doi.org/10.1016/S0022-4359(01)00064-1.

Ostrom, A. L., Parasuraman, A., Bowen, D. E., Patrício, L., \& Voss, C. A. (2015). Service research priorities in a rapidly changing context. Journal of Service Research, 18(2), 127-159. https://doi. org/10.1177/1094670515576315.

Pappas, I. O., Pateli, A. G., Giannakos, M. N., \& Chrissikopoulos, V. (2014). Moderating effects of online shopping experience on customer satisfaction and repurchase intentions. International Journal of Retail and Distribution Management, 42(3), 187-204. https://doi.org/10.1108/IJRDM-03-2012-0034.

Pham, T. S. H., \& Ahammad, M. F. (2017). Antecedents and consequences of online customer satisfaction: A holistic process perspective. Technological Forecasting and Social Change, 124, 332-342. https://doi.org/10.1016/j.techfore.2017.04.003.

Rajesh, R. (2020a). Exploring the sustainability performances of firms using environmental, social, and governance scores. Journal of Cleaner Production, 247, 119600. https://doi.org/10.1016/j.jclep ro.2019.119600.

Rajesh, R. (2020b). Sustainable supply chains in the Indian context: An integrative decision-making model. Technology in Society, 61(October 2019), 101230. https://doi.org/10.1016/j.techsoc.2020.101230.

Rajesh, R., \& Rajendran, C. (2020). Relating environmental, social, and governance scores and sustainability performances of firms: An empirical analysis. Business Strategy and the Environment, 29(3), 1247-1267. https://doi.org/10.1002/bse.2429.

Ringle, C. M., Wende, S., \& Becker, J.-M. (2015). SmartPLS 3. SmartPLS 3 (version3.2.1). Boenningstedt:SmartPLS gmbH. Bönningstedt: SmartPLS.

Roy Dholakia, R., \& Zhao, M. (2010). Effects of online store attributes on customer satisfaction and repurchase intentions. International Journal of Retail \& Distribution Management, 38(7), 482-496. https://doi.org/10.1108/09590551011052098.

Roy, S. K., Balaji, M. S., Sadeque, S., Nguyen, B., \& Melewar, T. C. (2017). Constituents and consequences of smart customer experience in retailing. Technological Forecasting and Social Change, 124, 257-270. https://doi.org/10.1016/j.techfore.2016.09.022. 
Roy, S. K., Shekhar, V., Lassar, W. M., \& Chen, T. (2018). Customer engagement behaviors: The role of service convenience, fairness and quality. Journal of Retailing and Consumer Services, 44, 293-304. https://doi.org/10.1016/j.jretconser.2018.07.018.

Seiders, K., Berry, L. L., \& Gresham, L. G. (2000). Attention, retailers! How convenient is your convenience strategy? Sloan Management Review. https://doi.org/10.1016/S0006-3495(95)80029-9.

Seiders, K., Voss, G. B., Godfrey, A. L., \& Grewal, D. (2007). SERVCON: Development and validation of a multidimensional service convenience scale. Journal of the Academy of Marketing Science, 35(1), 144-156. https://doi.org/10.1007/s11747-006-0001-5.

Sharma, B., Mathiyazhagan, K., Sehrawat, S., \& Elangovan, K. (2019). Assessing the challenging factors towards green initiatives in Indian electronic industries: A framework and evaluation. International Journal of Productivity and Quality Management, 26(4), 417. https://doi.org/10.1504/IJPQM .2019.10020989.

Siu, N. Y.-M. M., Wan, P. Y. K., \& Dong, P. (2012). The impact of the servicescape on the desire to stay in convention and exhibition centers: The case of Macao. International Journal of Hospitality Management, 31(1), 236-246.

Soopramanien, D. (2011). Conflicting attitudes and scepticism towards online shopping: The role of experience. International Journal of Consumer Studies, 35(3), 338-347. https://doi.org/10.111 1/j.1470-6431.2010.00945.x.

Thuy, P. N. (2011). Using service convenience to reduce perceived cost. Marketing Intelligence and Planning, 29(5), 473-487. https://doi.org/10.1108/02634501111153683.

Tsao, W. C., Hsieh, M. T., \& Lin, T. M. Y. (2016). Intensifying online loyalty! the power of website quality and the perceived value of consumer/seller relationship. Industrial Management and Data Systems, 116(9), 1987-2010. https://doi.org/10.1108/IMDS-07-2015-0293.

Van Loon, P., McKinnon, A. C., Deketele, L., \& Dewaele, J. (2014). The growth of online retailing: A review of its carbon impacts. Carbon Management, 5(3), 285-292. https://doi.org/10.1080/17583 004.2014 .982395 .

Venkatesh, V., Morris, M. G., Davis, G. B., \& Davis, F. D. (2003). User acceptance of information technology: Toward a unified view. MIS Quarterly, 27(3), 425-478. https://doi.org/10.2307/30036540.

Wakefield, K. L., \& Blodgett, J. G. (1996). The effect of the servicescape on customers' behavioral intentions in leisure service settings. Journal of Services Marketing, 10(6), 45-61. https://doi. org/10.1108/08876049610148594.

Wan, Y., Nakayama, M., \& Sutcliffe, N. (2012). The impact of age and shopping experiences on the classification of search, experience, and credence goods in online shopping. Information Systems and e-Business Management, 10(1), 135-148. https://doi.org/10.1007/s10257-010-0156-y.

Wolfinbarger, M., \& Gilly, M. C. (2012). Shopping online for freedom, control, and fun. California Management Review, 43(2), 34-55. https://doi.org/10.2307/41166074.

Xiao, L., Guo, F., Yu, F., \& Liu, S. (2019). The effects of online shopping context cues on consumers' purchase intention for cross-border e-commerce sustainability. Sustainability, 11(10), 2777. https://doi. org/10.3390/su11102777.

Yalch, R., \& Spangenberg, E. (1990). Effects of store music on shopping behavior. Journal of Consumer Marketing, 7(2), 55-63. https://doi.org/10.1108/EUM0000000002577.

Yang, K. (2012). Consumer technology traits in determining mobile shopping adoption: An application of the extended theory of planned behavior. Journal of Retailing and Consumer Services, 19(5), 484-491. https://doi.org/10.1016/j.jretconser.2012.06.003.

Yeo, V. C. S., Goh, S. K., \& Rezaei, S. (2017). Consumer experiences, attitude and behavioral intention toward online food delivery (OFD) services. Journal of Retailing and Consumer Services, 35, 150162. https://doi.org/10.1016/j.jretconser.2016.12.013.

Zeithaml, V. A., Berry, L. L., \& Parasuraman, A. (1996). The behavioral consequences of service quality. Journal of Marketing, 60(2), 31-46. https://doi.org/10.1177/002224299606000203.

Zeithaml, V. A., Bitner, M. J., \& Gremler, D. (2013). Services marketing: Integrating customer focus across the firm. New York: McGraw-Hill.

Publisher's Note Springer Nature remains neutral with regard to jurisdictional claims in published maps and institutional affiliations. 